\title{
Unilateral facet dislocations: Is surgery really the preferred option?
}

\author{
Authors Marcel Dvorak ${ }^{1}$, Alexander R Vaccaro ${ }^{2}$, Jeffrey Hermsmeyer ${ }^{3}$, Daniel C Norvell ${ }^{3}$ \\ Institutions ${ }^{1}$ University of British Columbia, Blusson Spinal Cord Centre, Vancouver BC, Canada \\ ${ }^{2}$ Thomas Jefferson University and the Rothman Institute, Philadelphia PA, USA \\ ${ }^{3}$ Spectrum Research Inc., Tacoma, Washington, USA
}

\section{ABSTRACT}

Study design: Systematic review.

Objective: To compare the safety and effectiveness of initial surgery versus nonoperative management of unilateral facet dislocations with or without fractures.

Summary of background: Unilateral facet injuries represent between $6 \%-10 \%$ of all cervical spine injuries and yet optimal treatment for these injuries has not been established. The surgeon is faced with the decision of whether to manage the injury operatively or nonoperatively. Providing evidence to support this decision is necessary and is the rationale behind this article.

Methods: A systematic review of the English language literature was undertaken for articles published between 1970 and August 2009. Electronic databases and reference lists of key articles were searched to identify studies evaluating surgery and nonoperative management of unilateral facet dislocations. Bilateral facet dislocations, isolated facet fractures (without dislocation), and complete spinal cord injuries were excluded. Two independent reviewers assessed the level of evidence quality using the GRADE criteria and disagreements were resolved by consensus.

Results: We identified six articles meeting our inclusion criteria. Treatment failure, neurological deterioration, and persistent pain occurred more frequently in patients treated nonoperatively versus patients treated with surgery. Surgical patients experienced infections and surgical related complications not experience by those managed nonoperatively. Patients treated surgically after failed nonoperative management also experienced better outcomes than those who continued to be managed nonoperatively.

Conclusion: When faced with a patient requesting treatment recommendations for their acute unilateral facet dislocation, the surgeon can state that treatment failure, persistent pain, and neurological deterioration occur more frequently with nonoperative treatment based on the available literature. Ultimately it will be the preference of the patient that will decide between these two treatment approaches. 


\section{STUDY RATIONALE AND CONTEXT}

Unilateral facet injuries represent $6 \%-10 \%$ of all cervical spine injuries and yet optimal treatment for these injuries is frequently in dispute. When faced with a patient in the emergency room, the treating spine surgeon is often asked to recommend either initial surgery or nonoperative treatment based on his/her experience and understanding of the literature. While patient preference is often a strong deciding factor, it is incumbent upon the surgeon to provide the patient with therapeutic advice that is most likely to return the patient to their pre-injury health status with the lowest risk of complications. This first decision, whether to operate or not, is thus very important. Often this decision is made not in the controlled environment of an elective office or clinic but more frequently in the emergency department and outside regular hours and may be influenced by resource availability, surgeon training, and local practice patterns. Providing evidence to support this decision and subsequent decisions, should initial nonoperative treatment fail, is necessary and is the rationale behind this article.

\section{OBJECTIVES}

To compare the safety and efficacy of initial surgery versus nonoperative management of unilateral facet dislocations with or without fractures and, among patients who experience failed nonoperative management, to compare outcomes of those who receive surgery versus those who do not receive surgery.

\section{MATERIALS AND METHODS}

Study design: Systematic review.

Sampling: Search: PubMed, Cochrane collaboration database, and National Guideline Clearinghouse databases; bibliographies of key articles.

Dates searched: 1970 to August 2009.

Inclusion criteria: (1) Unilateral facet dislocations with or without fractures, (2) Adults 18 years and older, (3) Studies including ten or more patients in either arm

Exclusion criteria: (1) Bilateral facet dislocation, (2) complete spinal cord injury, (3) isolated fracture without dislocation, (3) less than ten subjects per treatment, (4) data on unilateral facet dislocations not presented separately from other injuries.

Outcomes: Failed treatment, neurological deterioration, persistent pain, wound or surgical site infection, and complications (health-related or surgeryspecific).

Analysis: Descriptive statistics.

For more details see web appendix at www.aospine. org/ebsj.

\section{RESULTS}

We identified six articles meeting our inclusion criteria (Fig 1). Four studies evaluated operative or nonoperative treatment for unilateral facet dislocation. Two studies evaluated failed nonoperative treatment (inability to achieve and maintain reduction, a progression in neurological symptoms, or the presence of late pain and/or instability) that did or did not lead to future surgical management.

Operative versus nonoperative treatment of unilateral facet dislocations (Table 1 and Fig 2)

- One-hundred-and-seventy-six patients undergoing operative or nonoperative treatment were identified.

- Treatment failure rates were higher in nonoperatively managed patients $(80 \%)$ than surgically managed patients $(2.6 \%)$ [1-4].

- Neurological deterioration happened infrequently, but occurred more after nonoperative treatment $(5 \%)$ versus operative treatment $(0 \%)[1,2,4]$. 
- Posttreatment persistent pain occurred more frequently in nonoperative treatment $(30 \%)$ than it did in operative treatment $(10.3 \%)$ [1-4].

- Outcomes were not reported in the nonoperative treatment studies, but for operative treatment were reported as surgical site or deep wound infection $(7.8 \%)$ and general health or surgery specific complications $(13.8 \%)$ [1-4].

Failed nonoperative treatment that did or did not lead to future surgical management (Table 2)

- Forty-eight patients that had a failed nonoperative treatment who continued to be managed nonoperatively $(\mathrm{n}=28)$ or who subsequently went on to future surgery $(n=20)$ were identified.

- Failed anatomical reduction rates were higher among patients with continued nonoperative management $(100 \%)$ versus those who underwent surgical management $(30 \%)[5,6]$.

- Neurological deterioration occurred more frequently in continued nonoperative treatment $(10.7 \%)$ versus operative treatment $(0 \%)[5,6]$.

- Posttreatment persistent pain occurred more frequently in continued nonoperative treatment $(70 \%)$ than it did in operative treatment $(5 \%)[5,6]$.

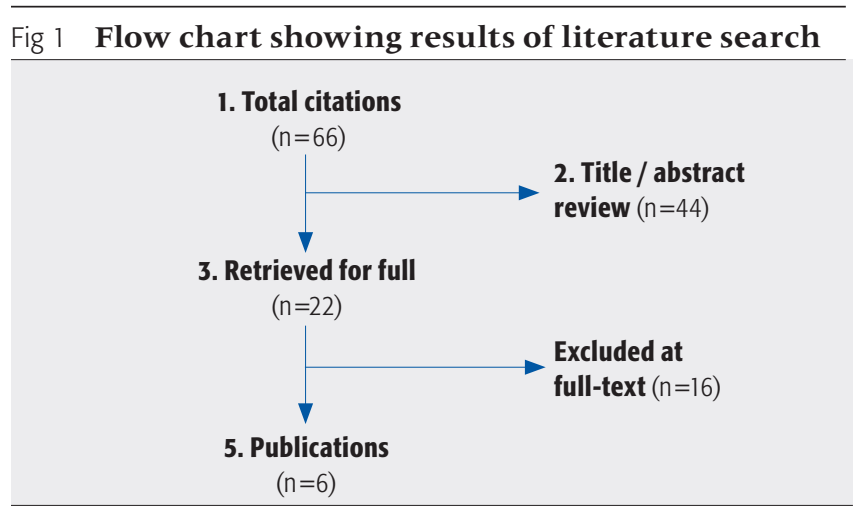

Fig 2 Outcomes rates comparing surgical to nonoperative management of unilateral facet dislocations

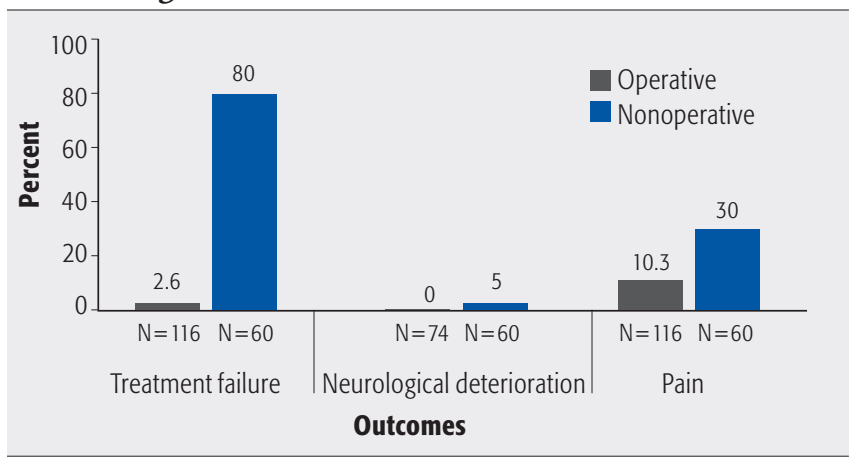

Table 1 Subject characteristics of studies evaluating operative versus nonoperative treatment for unilateral facet dislocation

\begin{tabular}{|c|c|c|c|c|c|c|c|c|}
\hline \multirow{2}{*}{$\begin{array}{l}\mathbf{N}=\mathbf{1 7 6} \\
\text { Outcomes }\end{array}$} & \multicolumn{4}{|c|}{ Operative $\mathrm{N}=116$} & \multicolumn{4}{|c|}{ Nonoperative $\mathbf{N}=60$} \\
\hline & Studies (n) & Patients (n) & Results (mean) & Results (range) & Studies (n) & Patients (n) & Results (mean) & Results (range) \\
\hline Treatment failure* & 4 & 116 & $2.6 \%$ & $0-6 \%$ & 2 & 60 & $80 \%$ & $77-82 \%$ \\
\hline Neurological deterioration ${ }^{\dagger}$ & 3 & 74 & $0 \%$ & $0 \%$ & 2 & 60 & $5 \%$ & $0-9 \%$ \\
\hline Wound or surgical infection & 4 & 116 & $7.8 \%$ & $0-12 \%$ & NR & NR & NR & NR \\
\hline Persistent pain & 4 & 116 & $10.3 \%$ & $0-14 \%$ & 2 & 60 & $30 \%$ & $27-32 \%$ \\
\hline Complications $\ddagger$ & 4 & 116 & $13.8 \%$ & $0-29 \%$ & NR & NR & NR & NR \\
\hline
\end{tabular}

* Defined in operative treatment as future subluxation, nonunion, or reoperation; defined in nonoperative treatment as failed anatomical reduction which may or may not lead to future surgical management.

$\dagger$ Defined as a negative change in neurological status from pre to postoperative.

F Including general health complications such as pneumonia and surgery-specific complications such as nerve palsy, dysphagia, difficulty swallowing, and wound site drainage.

Table 2 Subject characteristics of failed nonoperative treatment that may or may not lead to future surgical management

\begin{tabular}{lcccccccc}
$\mathbf{N}=\mathbf{4 8}$ & \multicolumn{2}{c}{ Operative $\mathbf{N = 2 0}$} & \multicolumn{3}{c}{ Nonoperative $\mathbf{N = 2 8}$} \\
\hline Outcomes & Studies (n) & Patients (n) & Results (mean) & Results (range) & Studies ( $n$ ) & Patients ( $n$ ) & Results (mean) & Results (range) \\
\hline Failed anatomical reduction & 2 & 20 & $30 \%$ & $20-40 \%$ & 2 & 28 & $100 \%$ & $100 \%$ \\
\hline Neurological deterioration* & 2 & 20 & $0 \%$ & $0 \%$ & 2 & 28 & $10.7 \%$ & $0-17 \%$ \\
\hline Persistent pain & 2 & 20 & $5 \%$ & $0-10 \%$ & 1 & 10 & $70 \%$ \\
\hline
\end{tabular}

* Defined as a negative change in neurological status from pre to postoperative. 


\section{EVIDENCE SUMMARY}

Question 1: Compare the safety and efficacy of initial surgery versus nonoperative management of unilateral facet dislocations

\begin{tabular}{|c|c|c|c|c|c|}
\hline \multirow{2}{*}{$\begin{array}{l}\text { Outcomes } \\
\text { 1. Treatment failure }\end{array}$} & \multicolumn{4}{|c|}{ Strength of evidence } & \multirow{2}{*}{$\begin{array}{l}\text { Conclusions/comments } \\
\text { Treatment failure rates are higher in } \\
\text { nonoperatively managed patients compared } \\
\text { to surgically managed patients. }\end{array}$} \\
\hline & Very low & Low & Moderate & High & \\
\hline 2. Neurological deterioration & Very low & Low & Moderate & High & $\begin{array}{l}\text { Neurological deterioration happened infrequently, } \\
\text { but occurred more frequently in nonoperative treatment } \\
\text { versus operative treatment. }\end{array}$ \\
\hline 3. Wound or surgical infection & Very low & Low & Moderate & High & $\begin{array}{l}\text { Rate of infection ranged from } 0 \%-12 \% \text { in } \\
\text { surgically managed patients. }\end{array}$ \\
\hline 4. Posttreatment pain & Very low & Low & Moderate & High & $\begin{array}{l}\text { Long term persistent pain occurred more } \\
\text { frequently in nonoperative treatment compared } \\
\text { to operative treatment. }\end{array}$ \\
\hline 5. Complications & Very low & Low & Moderate & High & $\begin{array}{l}\text { Complication rates occurred at a mean of } \\
13.8 \% \text { in surgically managed patients. }\end{array}$ \\
\hline
\end{tabular}

Details about the determination of strength of evidence can be found in the web appendix at www.aospine.org/ebsj

Question 2: Compare the safety and effectiveness of surgery versus nonoperative management after failed nonoperative management

\begin{tabular}{|c|c|c|c|c|c|}
\hline \multirow{2}{*}{$\begin{array}{l}\text { Outcomes } \\
\text { 1. Failed anatomical reduction }\end{array}$} & \multirow[b]{2}{*}{ Very low } & \multicolumn{3}{|c|}{ Strength of evidence } & \multirow{2}{*}{$\begin{array}{l}\text { Conclusions/Comments } \\
\text { Failed anatomical reduction rates are higher } \\
\text { in nonoperatively managed patients compared to surgically } \\
\text { managed patients. }\end{array}$} \\
\hline & & Low & Moderate & High & \\
\hline 2. Neurological deterioration & Very low & Low & Moderate & High & $\begin{array}{l}\text { Neurological deterioration was only reported } \\
\text { in patients who received continued nonoperative } \\
\text { management at mean of } 10.7 \% \text {. }\end{array}$ \\
\hline 3. Posttreatment pain & Very low & Low & Moderate & High & $\begin{array}{l}\text { Long term persistent pain occurred more } \\
\text { frequently in continued nonoperative treatment compared } \\
\text { to operative treatment. }\end{array}$ \\
\hline
\end{tabular}

Details about the determination of strength of evidence can be found in the web appendix at www.aospine.org/ebsj 


\section{DISCUSSION}

- In six case series that evaluated isolated unilateral facet dislocations, treatment failure, neurological deterioration, and persistent pain occurred more frequently in patients treated nonoperatively versus patients treated with surgery. Surgical patients experience infections and surgical related complications that those treated nonoperatively do not experience. Patients treated operatively after failed nonoperative management also experience better outcomes than those who continue to be managed (Tables 3-4).

- The existing literature reporting outcomes on the treatment of unilateral facet dislocations is limited to case series. No studies were identified that compared operative to nonoperative management in the same patient population. Pooled rates of treatment failure from these case series are remarkably higher in patients who are treated nonoperatively, but the potential for selection bias in this comparison is likely and therefore conclusions must be made with caution. Comparative studies are necessary to establish the efficacy of operative versus nonoperative management of these injuries.

- Although it is the facet that ultimately generates difficulty for realignment, the disc at the injured motion segment may also influence surgeon's decision making. Three of six studies reported surgical management of disc pathology.

- A discectomy at the injured level was performed in order to facilitate a fusion procedure regardless of whether or not disc herniation was documented by MRI [1].

- Discectomy was performed in five patients that had disc herniation as detected by MRI [4].

- The disc was excised if there was disc material dislodged into spinal canal [2].

However, none of these studies reported outcomes separately for those who had a discectomy versus those that did not. One study excluded from patient population all disc herniations documented by MRI [3]. In two studies there was no mention of disc disruption or disc herniation $[5,6]$.
- Although the quality of publications is lacking, there is remarkable consistency in the results across these studies. When faced with a patient requesting treatment recommendations for their acute unilateral facet dislocation, the surgeon can state that treatment failure, persistent pain, and neurological deterioration consistently occur more frequently with nonoperative treatment based on the available literature. It must be acknowledged that surgical treatment carries with it a complication rate likely around $10 \% \mathrm{t}-15 \%$. Similarly, there is consistent support for surgical treatment following failure of nonoperative care. Ultimately is will be the preference of the patient that will decide between these two treatment approaches. 


\section{ILLUSTRATIVE CASE (FIGS 3-10)}

A 43-year-old man was the unrestrained driver and sole occupant in a single vehicle roll-over high speed motor vehicle accident. The patient was found walking around at the scene of the accident. In the emergency room he complained of neck pain and facial and scalp abrasions. Neurological examination revealed right shoulder numbness, but no other neurological abnormality. He had no other injuries other than his cervical spine facet subluxation.

Anterior decompression was indicated to remove the posteriorly displaced disc fragment and combined anterior and posterior fixation provided reduction of the dislocated facet and stability. In the scenario of a subluxation, as opposed to dislocation, anterior discectomy, fusion, and plating are often effective treatment options. It is anticipated that his C5 radiculopathy would recover after treatment.

Fig 3 Lateral cervical spine plain $x$-ray demonstrates anterior subluxation of $\mathrm{C} 4$ on $\mathrm{C} 5$ of approximately $25 \%$ of the vertebral body diameter.

Fig 4 Axial CT scan

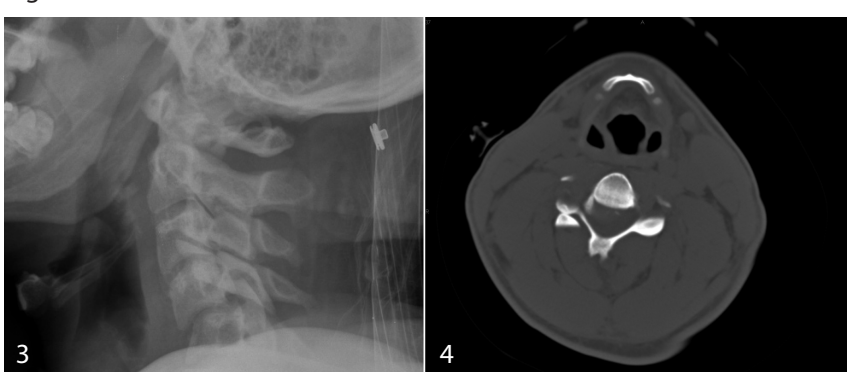

Fig 5 Reformatted image confirms a unilateral right sided facet dislocation at C4-5.

Fig 6 A second reformatted image confirms a unilateral right sided facet dislocation at C4-5.

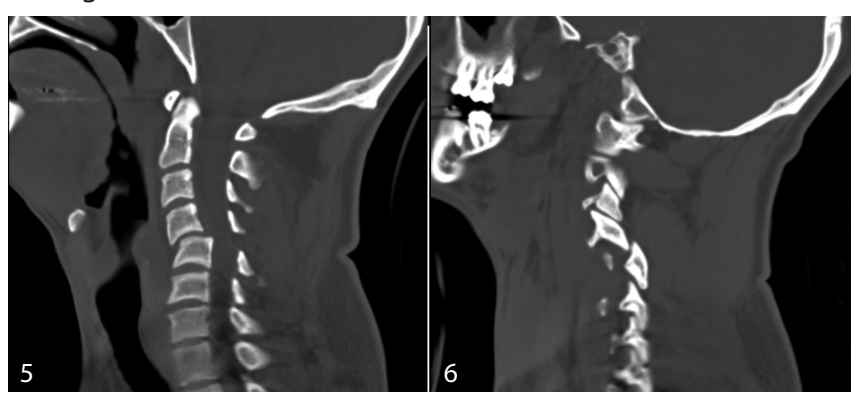

Fig 7 MRI imaging performed preoperatively revealed disc material posterior to the anteriorly subluxed body of $\mathrm{C} 4$.

Fig 8 Anterior discectomy was successful at decompression, however was not completely successful at reducing the dislocated facet joint.

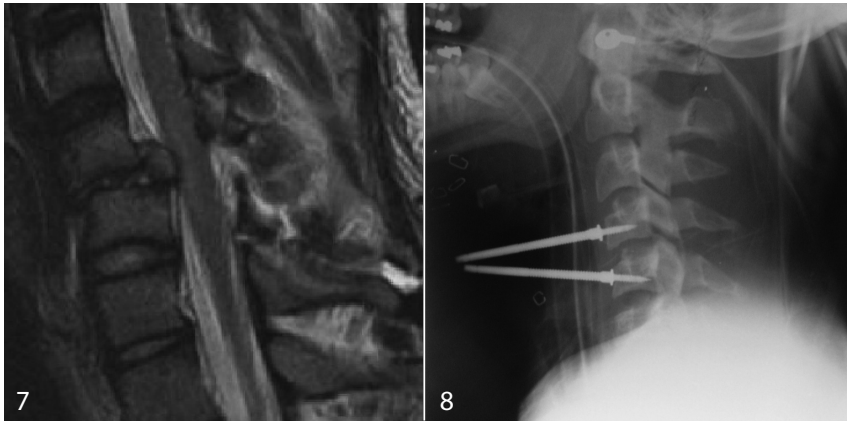

Figs 9-10 Lateral and AP views of combined anterior and posterior fixation which was ultimately necessary to stabilize this injury.

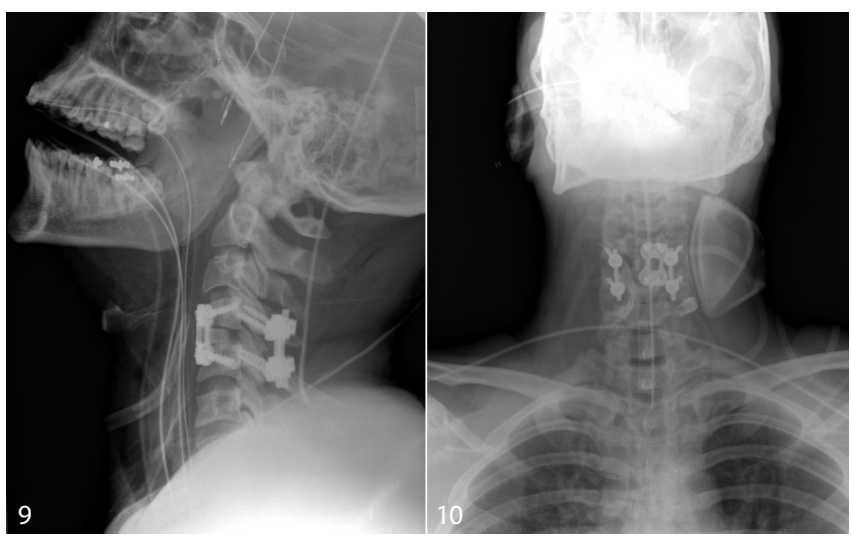




\section{Table 3 Subject demographics of studies evaluating operative versus nonoperative treatment} for unilateral facet dislocation

\begin{tabular}{|c|c|c|c|c|c|}
\hline $\begin{array}{l}\text { Author } \\
\text { (Year) }\end{array}$ & $\begin{array}{l}\text { Study } \\
\text { type }\end{array}$ & Population & Dislocation characteristics & Treatment & Follow-up \\
\hline 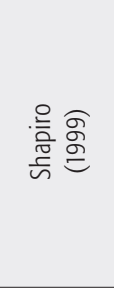 & 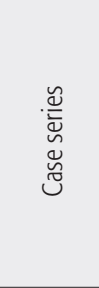 & $\begin{array}{l}\mathrm{N}=46 \\
\text { Age: } 30 \text { years }(19-52) \\
86 \% \text { male }\end{array}$ & $\begin{array}{l}\text { Unilateral cervical facet dislocation } \pm \\
\text { fractures; single level dislocation }\end{array}$ & $\begin{array}{l}\text { Surgery: } \\
\text { Posterior reduction and/or internal fixation } \\
\text { ( } n=46,100 \%) \\
\text { - First } 24 \text { patients underwent spinous } \\
\text { process wire fixation } \\
\text { - Additional } 22 \text { patients underwent } \\
\text { interspinous wiring with braided cable } \\
\text { for lateral mass plating }\end{array}$ & $\begin{array}{l}\text { Mean follow-up: } \\
\text { - Spinous process wire group: } \\
102 \text { months } \\
\text { - Cable and lateral mass plate } \\
\text { group: } 40 \text { months } \\
\text { - Follow-up rate: } 86 \% \\
\text { - Follow-up range: } 12-120 \\
\text { months }\end{array}$ \\
\hline 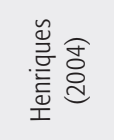 & 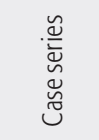 & $\begin{array}{l}\mathrm{N}=17 \\
\text { Age: } 47 \text { years }(17-82) \\
94 \% \text { male }\end{array}$ & $\begin{array}{l}\text { Distractive flexion injuries } \\
\text { Stage } 2 \text { (unilateral facet) } \pm \text { fractures } \\
\text { 2-level dislocation } n=3\end{array}$ & $\begin{array}{l}\text { Anterior fixation } \\
(n=17,100 \%)\end{array}$ & $\begin{array}{l}\text { Mean follow-up: } \\
\text { - } 15 \text { months } \\
\text { - Follow-up rate: NR }\end{array}$ \\
\hline 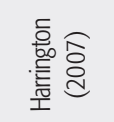 & 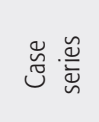 & $\begin{array}{l}\mathrm{N}=11 \\
\text { Age: } 42 \text { years }(22-65) \\
55 \% \text { male }\end{array}$ & $\begin{array}{l}\text { Single-level } \\
\text { unilateral facet injuries } \pm \text { fractures }\end{array}$ & $\begin{array}{l}\text { Anterior cervical discectomy, distraction } \\
\text { reduction with allograft fusion and anterior } \\
\text { cervical plating }\end{array}$ & $\begin{array}{l}\text { - Follow-up } 30 \text { days } \\
\text { - Follow-up rate: } 100 \%\end{array}$ \\
\hline 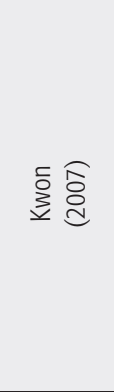 & 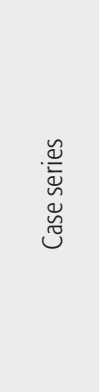 & $\begin{array}{l}\text { Anterior fixation } n=20 \\
\text { Age: } 38 \text { years }(17-86) \\
70 \% \text { male } \\
\text { Posterior fixation } n=22 \\
\text { Age: } 33 \text { years }(17-69) \\
77 \% \text { male }\end{array}$ & $\begin{array}{l}\text { Single-level unilateral facet injury } \pm \\
\text { fractures }\end{array}$ & $\begin{array}{l}\text { Anterior fixation: } \\
\text { anterior cervical discectomy and fusion } \\
(n=20,47 \%)\end{array}$ & $\begin{array}{l}\text { Anterior fixation follow-up rate: } \\
14 / 20(70 \%) \text { at } 12 \text { months } \\
\text { Posterior fixation follow-up } \\
\text { rate: } 19 / 22(86 \%) \text { at } 12 \text { months }\end{array}$ \\
\hline 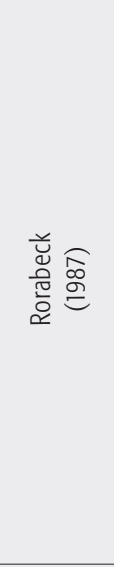 & 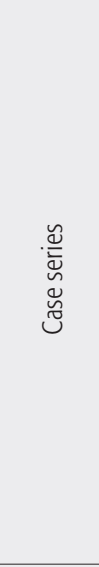 & $\begin{array}{l}N=26 \\
\text { Age: } 37 \text { years }(17-74) \\
85 \% \text { male }\end{array}$ & $\begin{array}{l}\text { Isolated } \\
\text { unilateral facet dislocation } \\
n=12 \\
\text { Fracture of facet or associated body } \\
\text { fracture } n=14\end{array}$ & $\begin{array}{l}\text { Initial treatment consisted of either } \\
\text { skull-tong or halo traction } \\
\text { ( } \mathrm{n}=26,100 \%) \\
\text { - Six }(23 \%) \text { patients experienced } \\
\text { reduction with traction } \\
\text { - Two treated nonoperatively with } \\
\text { halo thoracic vest } \\
\text { - Four underwent one-level posterior } \\
\text { fusion } \\
\text { - Twenty (77\%) did not experience } \\
\text { reduction } \\
\text { - Ten (38.5\%) left in displaced position, } \\
\text { ambulated with external bracing } \\
\text { - Ten (38.5\%) underwent open } \\
\text { reduction and single-level posterior } \\
\text { fusion }\end{array}$ & $\begin{array}{l}\text { Mean follow-up: } \\
-3 \text { years } \\
\text { - Follow-up rate: } 100 \%\end{array}$ \\
\hline \multirow[b]{2}{*}{ ¿্ঠ } & \multirow[b]{2}{*}{ 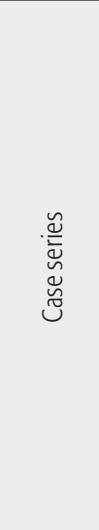 } & $\begin{array}{l}\mathrm{N}=36 \\
\text { Age: } 33 \text { years (15-87) } \\
78 \% \text { male } \\
\text { *2 patients lost to follow-up }\end{array}$ & \multirow[t]{2}{*}{$\begin{array}{l}\text { Unilateral facet dislocations or } \\
\text { fracture-dislocations with } \\
n=2 \text { at multiple levels }\end{array}$} & $\begin{array}{l}\text { Initial treatment }(N=34) \text { : } \\
\text { - Closed reduction with halo traction } \\
(n=28) \text {, halo traction alone }(n=1) \text {, } \\
\text { immobilization with cervical brace } \\
(n=4) \text {, and no treatment }(n=1)\end{array}$ & $\begin{array}{l}\text { Mean nonoperative follow-up: } \\
\text { nearly } 9 \text { years } \\
\text { Mean operative follow-up: } \\
6.5 \text { years }\end{array}$ \\
\hline & & $\begin{array}{l}\text { INonoperative: } \\
\text { Age: } 30 \text { years }(16-74) \\
\text { Operative: } \\
n=10 \\
\text { Age: } 33 \text { years }(15-71)\end{array}$ & & $\begin{array}{l}\text { Operative treatment }(n=10) \text { : } \\
\text { Indications for surgery included: } \\
\text { - Persistence or progression of neural } \\
\text { deficit }(n=4) \\
\text { - Failed reduction }(n=3) \\
\text { - Loss of reduction }(n=3) \\
\text { Operative treatment consisted of open } \\
\text { reduction through posterior approach and } \\
\text { fusion with interspinous wiring }\end{array}$ & $\begin{array}{l}\text { Follow-up rate for both groups: } \\
94 \% \\
2 \text { patients lost to follow-up }\end{array}$ \\
\hline
\end{tabular}




\begin{tabular}{|c|c|c|c|c|c|c|}
\hline $\begin{array}{l}\text { Author } \\
\text { (Year) }\end{array}$ & $\begin{array}{l}\text { Treatment } \\
\text { failure } \mathbf{N}(\%)\end{array}$ & $\begin{array}{l}\text { Neurological } \\
\text { deterioration } \mathbf{N}(\%)\end{array}$ & Infection N (\%) & Pain N (\%) & Complications $\mathbf{N}(\%)$ & Significant findings \\
\hline $\begin{array}{l}\text { 응 } \\
\text { 号 } \\
\text { こ }\end{array}$ & $\begin{array}{l}1(2 \%) \\
\text { Experienced } \\
\text { resubluxation } \\
\text { and underwent } \\
\text { reoperation of } \\
\text { anterior cervical } \\
\text { fusion and } \\
\text { plating }\end{array}$ & $0(0 \%)$ & $3(6 \%)$ & $\begin{array}{l}6(13 \%) \\
\text { - Persistent neck } \\
\text { pain in } 4(17 \%) \text { of } \\
\text { spinous process } \\
\text { wire group } \\
\text { - Persistent neck } \\
\text { pain in } 2(9 \%) \text { of } \\
\text { cable and lateral } \\
\text { mass plate group }\end{array}$ & $\begin{array}{l}\text { No other complications } \\
\text { reported }\end{array}$ & $\begin{array}{l}\text { - No deaths } \\
\text { - Spinous process wire group } \\
\text { had } 11(46 \%) \text { perfect } \\
\text { anatomical alignment } \\
\text { compared to } 14(64 \%) \text { cable } \\
\text { and lateral mass plate group }\end{array}$ \\
\hline 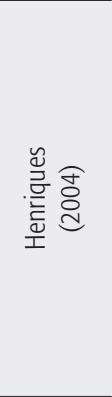 & $\begin{array}{l}1(5.9 \%) \\
\text { Patient with } \\
\text { 2-level injury } \\
\text { reoperated with } \\
\text { anterior fusion } \\
\text { due to nonunion }\end{array}$ & $0(0 \%)$ & $0(0 \%)$ & $0(0 \%)$ & $\begin{array}{l}\text { - Developed unilateral } \\
\text { recurrent laryngeal nerve } \\
\text { palsy secondary to } \\
\text { surgical approach in } 1 \\
(2.8 \%) \\
\text { - Transient dysphagia in } 1 \\
(2.8 \%) \\
\text { - Injury of the lateral } \\
\text { cutaneous femoral nerve } \\
\text { as a result of bone graft } \\
\text { harvesting in } 1(2.8 \%)\end{array}$ & $\begin{array}{l}\text { - Two (66\%) of the three } \\
\text { patients with 2-level injuries } \\
\text { developed nonunion at one } \\
\text { level } \\
\text { - One nonunion patient } \\
\text { reoperated with anterior } \\
\text { fusion while reoperation not } \\
\text { necessary in the other as } \\
\text { patient free of symptoms }\end{array}$ \\
\hline 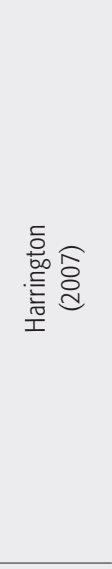 & $0(0 \%)$ & $\begin{array}{l}0(0 \%) \\
\text { Preoperative ASIA } \\
\text { E-7 (64\%) } \\
\text { D-4 (36\%) } \\
\text { Postoperative ASIA } \\
\text { E-8 }(73 \%) \\
\text { D-3 (27\%) } \\
\text { One preoperative ASIA } \\
\text { score of D improved to E } \\
\text { postoperatively. All other } \\
\text { preoperative ASIA scores } \\
\text { did not change } \\
\text { postoperatively. }\end{array}$ & $1(9.1 \%)$ & $\begin{array}{l}0(0 \%) \\
\text { No pain in } \\
\text { any patient } \\
\text { as evidence } \\
\text { of stability }\end{array}$ & $\begin{array}{l}\text { Ventilator-related } \\
\text { pneumonia in } 1 \text { (9.1\%) } \\
\text { patient requiring } \\
\text { tracheotomy }\end{array}$ & $\begin{array}{l}\text { Translational subluxation: } \\
\text { Preop } 5-1 \mathrm{~mm} \text {; } \\
\text { Postop } 0-3.5 \mathrm{~mm} \\
\text { Sagittal rotation: } \\
\text { Preop }-15 \text { to }+16^{\circ} \\
\text { Postop }-11 \text { to }+6^{\circ}\end{array}$ \\
\hline 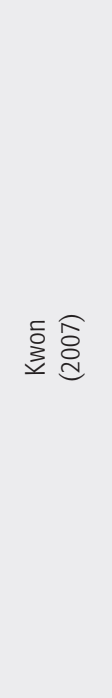 & $\begin{array}{l}1(2.4 \%) \\
\text { Posterior fixation } \\
\text { patient } \\
\text { developed } \\
\text { pseudoarthrosis } \\
\text { and required } \\
\text { anterior revision }\end{array}$ & $\begin{array}{l}\text { Anterior fixation: } \\
\text { Neurological component } \\
\text { of NASS cervical spine } \\
\text { questionnaire: } 85.2 \text { (100 } \\
\text { optimal) } \\
\text { Posterior fixation: } \\
\text { Neurological component } \\
\text { of NASS cervical spine } \\
\text { questionnaire: } 83.9 \text { (100 } \\
\text { optimal) } \\
\text { Baseline neurological } \\
\text { status not measured so } \\
\text { deterioration cannot be } \\
\text { calculated. }\end{array}$ & $\begin{array}{l}\text { Anterior fixation: } \\
1(5 \%) \\
\text { Infection at bone } \\
\text { graft site at } 3 \text { weeks } \\
\text { Posterior fixation: } \\
4(18 \%) \\
\text { Superficial wound } \\
\text { infection at 2-3 } \\
\text { weeks in three } \\
\text { patients (14\%) } \\
\text { MRSA wound } \\
\text { infection in one } \\
\text { patient (4\%) }\end{array}$ & $\begin{array}{l}\text { Anterior fixation: } \\
\text { Score of }>5 \text { out of } \\
10 \text { VAS pain in } \\
\text { three }(15 \%) \\
\text { patients } \\
\text { Posterior fixation: } \\
\text { Score of }>5 \text { out of } \\
10 \text { VAS pain in } \\
\text { three }(13.6 \%) \\
\text { patients }\end{array}$ & $\begin{array}{l}\text { Anterior fixation: } \\
\text { Severe medical } \\
\text { complications acutely } \\
\text { postop in one patient (5\%) } \\
\text { Swallowing difficulties in } 11 \\
(55 \%) \\
\text { Posterior fixation: } \\
\text { No other complications } \\
\text { reported }\end{array}$ & $\begin{array}{l}\text { Median time to achieve } \\
\text { discharge criteria: } \\
\text { Anterior } 2.75 \text { (1-24) days; } \\
\text { Posterior } 3.5 \text { (1.5-42) days } \\
\text { VAS pain score on } \\
\text { postoperative day 1: } \\
\text { Anterior 2.6; Posterior 3.6 } \\
\text { and on postoperative day 2: } \\
\text { Anterior 2.1; Posterior } 3.0 \\
\text { No difference in anterior versus } \\
\text { posterior regarding SF-36 } \\
\text { mental and physical scores and } \\
\text { for NASS cervical and } \\
\text { neurological scores } \\
\text { Fusion rate available for } \\
\text { patients at 12-month } \\
\text { follow-up: Anterior } 100 \% \\
\text { (18/18); Posterior 89\% (17/19) }\end{array}$ \\
\hline
\end{tabular}




\begin{tabular}{|c|c|c|c|c|c|c|}
\hline $\begin{array}{l}\text { Author } \\
\text { (Year) }\end{array}$ & $\begin{array}{l}\text { Treatment } \\
\text { failure } \mathbf{N}(\%)\end{array}$ & $\begin{array}{l}\text { Neurological } \\
\text { deterioration } \mathbf{N}(\%)\end{array}$ & Infection N (\%) & Pain N (\%) & Complications N (\%) & Significant findings \\
\hline 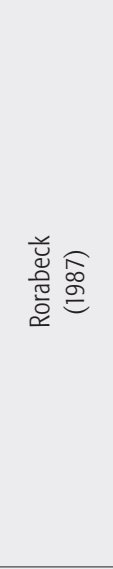 & $\begin{array}{l}20(77 \%) \\
\text { Did not } \\
\text { anatomically } \\
\text { reduce after } \\
\text { initial treatment } \\
\text { of skull-tong or } \\
\text { halo traction }\end{array}$ & $0(0 \%)$ & NR & $\begin{array}{l}7(26.9 \%) \\
\text { - No patient (0\%) } \\
\text { that experienced } \\
\text { reduction with } \\
\text { traction had pain } \\
\text { at follow-up } \\
\text { - Of ten patients } \\
\text { left in displaced } \\
\text { position seven } \\
\text { (70\%) had } \\
\text { disabling pain } \\
\text { - Of ten patients } \\
\text { that underwent } \\
\text { open reduction } \\
\text { 0\% had pain at } \\
\text { follow-up }\end{array}$ & $\begin{array}{l}\text { - Five of seven patients left } \\
\text { in displaced position and } \\
\text { having significant } \\
\text { disabling pain went on to } \\
\text { surgical anterior or } \\
\text { posterior fusion } \\
\text { - Two of ten patients } \\
\text { receiving open reduction } \\
\text { and single-level fusion did } \\
\text { not have a successful } \\
\text { reduction }\end{array}$ & $\begin{array}{l}\text { Patients left in displaced } \\
\text { position and allowed to heal in } \\
\text { that position develop late pain }\end{array}$ \\
\hline 产 & $\begin{array}{l}22(64.7 \%) \\
\text { patients did not } \\
\text { achieve } \\
\text { anatomical } \\
\text { reduction: } \\
\text { - } 15 \text { patients had } \\
\text { imperfect } \\
\text { reduction } \\
\text { - seven patients } \\
\text { (all in } \\
\text { nonoperative } \\
\text { treatment } \\
\text { group) were } \\
\text { left in } \\
\text { dislocated } \\
\text { position }\end{array}$ & $\begin{array}{l}\text { Full population: } \\
3(8.8 \%) \\
\text { Nonoperative: } \\
3(13 \%) \\
\text { Showed no change or } \\
\text { possibly deterioration at } \\
\text { follow-up } \\
\text { Operative: } \\
0(0 \%)\end{array}$ & NR & $\begin{array}{l}\text { Full population: } \\
11(32.4 \%) \\
\text { Nonoperative: } \\
10(42 \%) \\
\text { Operative: } \\
1(10 \%)\end{array}$ & $\begin{array}{l}\text { Halo traction not effective } \\
\text { as a means of obtaining } \\
\text { closed reduction } \\
\text { - Ten (36\%) achieved } \\
\text { anatomical reduction } \\
\text { - Seven (25\%) remained } \\
\text { dislocated } \\
\text { - Eleven (39\%) showed } \\
\text { some improvement }\end{array}$ & $\begin{array}{l}\text { - Cervical translation, at or } \\
\text { adjacent to the injury level, } \\
\text { seen more frequently w/ } \\
\text { nonoperative treatment } \\
\text { (38\%) versus operative } \\
(20 \%) \\
\text { - Solid fusion in ten (100\%) } \\
\text { patients treated operatively } \\
\text { - Spontaneous fusion in } 13 \\
\text { patients (54\%) in } \\
\text { nonoperative group } \\
\text { - Anatomical reduction was } \\
\text { attained more frequently by } \\
\text { operative intervention (60\% } \\
\text { versus } 25 \%) \\
\text { - Less than anatomical } \\
\text { reduction is a risk factor for } \\
\text { cervical translation, } \\
\text { regardless of treatment }\end{array}$ \\
\hline
\end{tabular}

\section{REFERENCES}

1. Harrington JF, Jr, Park MC (2007) Single level arthrodesis as treatment for midcervical fracture subluxation: a cohort study. J Spinal Disord Tech; 20:42-48.

2. Henriques T, Olerud C, Bergman A, et al (2004) Distractive flexion injuries of the subaxial cervical spine treated with anterior plate alone. J Spinal Disord Tech; 17:1-7.

3. Kwon BK, Fisher CG, Boyd MC, et al (2007) A prospective randomized controlled trial of anterior compared with posterior stabilization for unilateral facet injuries of the cervical spine. J Neurosurg Spine; 7:1-12.
4. Shapiro S, Snyder W, Kaufman K, et al (1999) Outcome of 51 cases of unilateral locked cervical facets: interspinous braided cable for lateral mass plate fusion compared with interspinous wire and facet wiring with iliac crest. J Neurosurg; 91:19-24.

5. Beyer CA, Cabanela ME, Berquist TH (1991) Unilateral facet dislocations and fracture-dislocations of the cervical spine. J Bone Joint Surg Br; 73:977-981.

6. Rorabeck CH, Rock MG, Hawkins RJ, et al (1987) Unilateral facet dislocation of the cervical spine. An analysis of the results of treatment in 26 patients. Spine (Phila Pa 1976); 12:23-27. 